\title{
Influence of Capital Structure on Sustainability of Community Water Projects
}

\author{
Solomon Muriungi Mburung'a
}

\begin{abstract}
The purpose of this study was to investigate the influence of capital structure on sustainability of community water projects. The objective of the study was to investigate influence of capital structure (equity financing-community's contribution; debt financing; grant financing-donor funds; and water tariffs) on sustainability of community water projects. The study adopted a cross-sectional descriptive survey design and data was collected using questionnaires, interview schedules and observation schedules. Both descriptive and inferential statistics were used in analysis. The study established that, there was significant but moderately weak positive relationship between equity financing (community's contributions) and level of sustainability of community water projects. In addition, there was a weak negative relationship between grant financing and level of sustainability of community water projects. Hence, increase in grants reduces the levels of sustainability of a community water project. None of the projects utilized any debt finance such as loans in their capital structure. Finally, there was a significant moderate positive relationship between water user fee and sustainability of community water projects. The study recommends that, communities should give more of their own resources while donors should, either reduce or insist on refund for funds donated to improve sustainability of community water projects.
\end{abstract}

Keywords: Sustainability, Community Water Projects, Capital Structure.

\section{Introduction}

\subsection{Background of the Study}

Water is indispensable for life. In addition water is used in all economic and social development. However, according to World Bank (2013), over 783 million people globally cannot access clean and reliable water sources. The situation is worse in Africa where 300 million people lack access to safe drinking water (African Development Fund, 2005). This lack of water poses great challenges to developing countries. Globally, poor sanitation in most cases due to lack of clean water led to 700,000 premature deaths annually. In addition, high cases of sanitation diseases increase the cost of health care treatment which leads to loss of time in productive activities while seeking treatment. Lack of water therefore, is a huge economic costs to developing countries and households especially in rural areas (World Bank, 2011).

The world recommended domestic water use is 50 litres per capita per day. According to Yahaya (2004), 55 countries have not met his target and 35 of them are in Sub-Saharan Africa. In this region, due to rural urban migration, the urban dwellers not accessing safe drinking water doubled from 1990 to 2004 (WHO \& UNICEF, 2006). In Kenya, in the year 2013, 41\% do not have access to drinking water, that is, $17 \%$ in urban areas and $48 \%$ in rural areas, had no access to access to clean drinking water (WHO and UNICEF, 
2013).

Global efforts are being put to meet the set new global Sustainable Development Goal (SDG) number six to ensure availability and sustainable management of water and sanitation for all by the year 2030. Under goal 6.1, the target is to achieve universal and equitable access to safe and affordable drinking water for all. To this end, many national governments and non-governmental organizations have allocated substantial resources in initiating water projects especially in rural areas which are managed by communities.

These efforts will not bear fruits in future if sustainability of the existing water projects is not considered. Kimberly (1998) defined sustainability as the process of ensuring a project systems and interventions continue to operate and function well and be able to generate benefits over time as designed. Sustainability, therefore, is the ability of a water project to operate and maintain initial project service standards over time. According to Sutton (2004) there are huge number of non-functioning water systems and systems functioning below expectations. In a survey of 11 countries in Africa, between 35-80 percent of the water systems are functioning in rural areas. A study on borehole sustainability in South African found out that, 70 percent were not functioning. In Tanzania, a Sub Saharan Country, the functioning water supply systems that were initiated 25 years or older were only 10 percent (Haysom, 2006).

Kenya is one of the top ten of countries where large population cannot access drinking water. Access to water in Kenya stood at 51 percent nationally (UNICEF \& WHO, 2012). Large investments both by foreign donors and national government were made to supply water to Kenyan rural people. Studies have shown majority of the new water supplies projects stop functioning few years after construction (Ministry of Water and Irrigation, 2007; and Rural Water Supply Networks, 2007).

Studies on sustainability of rural water projects in different countries in Africa by Adida (2012) in Western Kenya, Harvey and Reed (2007), Beyene (2012) in Ethiopia, Abrams (1998), Mukherjee and Van Wijk (2002), Musonda (2004) in Zambia, and Shaw (2012) in Zambia, concluded that, non supporting water policy context; financial and economic issues; non-flexible institutional arrangements; lack of spare parts supply; community and social aspects; ; poor maintenance of projects; poor technology and the natural environmental issues, and lack of proper monitoring affect sustainability of water projects negatively. None of these studies focused on capital structure as influencing sustainability of water projects. Therefore, this study investigated influence of capital structure on sustainability of community water supply in Kieni Constituency, Nyeri County, in Kenya.

\subsection{Objective of the Study}

The study aimed at achieving the following objectives, to:-

(i) Establish the extent to which equity financing influences sustainability of community water projects in Kieni Constituency.

(ii) Assess the extent to which grant financing influence sustainability of community water projects in Kieni Constituency.

(iii) To examine the extent to which debt financing influences sustainability of community water projects in Kieni Constituency.

(iv) Establish the influence of the water user fees on sustainability of community water 
projects in Kieni Constituency.

(v) Investigate influence of capital structure (combined influence of equity financing, grant financing and water user fee) on sustainability of community water projects in Kieni Constituency.

\subsection{Study Hypotheses}

$\mathrm{H}_{01}$-there was no significant relationship between equity financing and sustainability of the community water projects.

$\mathrm{H}_{02}$ there is no significant relationship between debt financing and sustainability of community water projects.

$\mathrm{H}_{03}$ there is no significant relationship between grant financing and sustainability of community water projects.

$\mathrm{H}_{04}$ there is no significant relationship between water user fees and sustainability of community water projects.

$\mathrm{H}_{05}$ there is no significant relationship between capital structure, (that is, the combined effect of equity financing, debt financing, grant financing and water user fee) on sustainability of community water projects.

\subsection{Limitations and Assumptions of the Study}

The study focused on community water projects only. Therefore, private companies and Government water supply systems were excluded from the study. The study made an assumption that the respondents gave truthful and accurate information for valid conclusions.

\section{Literature Review}

\subsection{Water Sector and Financing}

Water projects require enormous resources to establish and sustain. Water projects are capital-intensive investments (UNEP, 2006). According to United States Environmental Protection Agency (2014), the estimated worldwide water infrastructure spending was \$22 trillion. In Kenya, just like many Sub-Saharan African countries, water budgetary expenditure has been on the rise. For instance, water sector budgetary allocation increased by 29 per cent from Ksh. 26.5 billion ( $\$ 265$ million) in the financial year 2011/12 to Ksh. 34.4 billion (\$344 million) in 2013/14 (Republic of Kenya, 2013).

Apart from Government Budgetary allocation, community members and foreign donors, through bilateral and multilateral grants, finance water projects in Kenya. For instance, according to OECD (2008), Kenya is among the top recipient of water financing aid. Kenya, by the year 2006 received $\$ 29.5$ million from France, \$14.6 from Germany, \$0.6 million from Ireland, \$13.5 million from Sweden, \$2.8 million from US among other donors from other countries. These are enormous resources that were committed to improvement of water supply and sanitation yet around 41 percent of Kenyans lack access to drinking water.

\subsection{Capital Structure and Sustainability of Water Projects}

Capital structure refers to the proportion of sources of money such as equity 
finance, (owners' contribution), debt finance (funds to be repaid) and grant finance (free funds). According to Nonprofit Finance Fund (2009) and Miller (2002), capital structure varies for non-profits and profits institutions and is a very important factor for survival of an organization. However, scholars finance scholars documented that there is no right kind of capital structure for all organizations.

Maintaining a healthy capital structures is hard for non-profit sector due to restrictions on assets (McLaughlin, 2000), and that includes community water projects. Most community projects cannot own assets which could act as collateral for debt finance therefore have a restricted capital structure. This is because they are not legal entities such as companies. Therefore, the remaining sources of funds include community contributions (equity finance), donor aid, water user fees and government grants.

\subsection{Equity Financing/ Community Contributions}

Equity finance is the finance provided by real owners of the company, that is, the ordinary shareholders who are real owners of the company (Cheong, 2016). In this study, equity financing refers to the funds contributed by the community members for construction of a water project that is expected to benefit them.

According to World Bank (1992), when communities contribute their resource in a joint project, it confers and fosters community support for project; it helps resolve conflict over resource use and brings ownership to the project. In another study by Gow and Franken (1994), financial contribution by a community is a sure way of enhancing sustainability of benefits from a joint project. I other studies by Kikula (1999) and Nyong \& Kanaroglou (1999) concluded that, community water projects that have effective social structures and backed by financial contribution, are more likely to get full community support than projects whereby communities do not contribute own resources.

\subsection{Grant Financing and Sustainability of Water Projects}

A grant is a financial or material resource given by a donor or funding agency for the purpose of achieving specific objectives and contributing towards predefined goals and without expectations for repayment (Miller, 2002).

Adam and Bevan (2006) and Nkusu (2004) found out that, grants often leads to a "Dutch Disease Syndrome". This is a situation created by large inflows of foreign aid to country that results in lack of sustainability of development projects. The theory explains that large grants have negative effects on communities' productivity. This is by impairing their competitiveness (Adam and Bevan 2006; Nkusu 2004). This syndrome could affect negatively the motivation of recipients of grants to monitor effectively projects. This is because community members believe "it is not their money" that has been used in the project. This in most cases lead to negative effects such as neglect of the project Swaroop and Devarajn (1998) documented another negative effect of free money or grants and they termed it "fungibility". According to them, grants intended for the social and economic improvements in standards of living, may result in wastage of the funds and other resources they would have been spent on improvement of welfare. In a community water project, grants from donors may free the community members funds that could have otherwise been utilized in the project to other anti-development social 
activity such as heavy drinking of alcohol among others, thereby making the community worse off.

Grants or aid generally do not include allocations for overhead expenditures for operation and maintenance. According to Young (2002), most donors do not meet the full costs of a project, especially the operating expenses of the project. As a result, most projects scramble for additional funds and the cost of obtaining extra resources are usually high and do not benefit the projects, there by affecting projects negatively (Young, 2002).

\subsection{Water User Fee and Sustainability of Water Projects}

Water tariffs levying is subjected to two ideological views according to Whittington (2003). The first view, water as a social good necessary for existence, and therefore, it should be provided free of charge. The second view, water is seen as an economic good that should be priced and not provided for free. However, there has been consensus that water should not be provided for free but the price charged should be fair (Boland and Whittington, 2000). Provision of free water supply encourages wastage and promotes unsustainable use of water. In addition, governments can no longer afford to provide water for free.

A study by Gine and Perez-Foguet (2008) on sustainability of national rural water supply program in Tanzania established that, failure of a community project to generate sufficient revenues through water tariffs leads to lack of sustainability. This is because repairs and general maintenance will not be done. They recommended that, communities need to choose cheaper but efficient water technologies and set tariffs that are affordable. Meaning that, the water tariffs should be commensurate with the economic status of water beneficiaries. Baumann (2006) added that, inability of communities to collect sufficient revenue for maintenance reduce the life expectancy of water supplies systems. Kleemeier (2000) stated that community members in Africa were reluctant to pay when everything appears to be working. While Whittington et al (2008) observed that, in most rural communities incomes are seasonal and have very little savings. Therefore, many community water projects cannot generate enough of water revenue through water tariffs to cater for operation and maintenance of the established water systems.

\subsection{Sustainability of Community Water Supply Projects}

The most popular definition of sustainability is drawn from the 1987 report of the United Nation World Commission on Environment and Development which defined sustainability as "meeting the needs of the present without compromising the ability of future generations to meet their own needs". World Bank (2011) defined sustainability as the ability of a project to generate expected benefit through its economic life. WHO (2000) defined sustainability as "ability of a project to continue to function effectively for the foreseeable future, with high treatment coverage, integrated into available health care services, with strong community ownership using resources mobilized by the community and government".

Abrams (1998) in defining the concept of sustainability of water services refers to a sustainable intervention as one which continues to operate over time. Abrams viewed sustainability of water projects as a "continued flow of water at the same rate and quality as 
when the supply system was designed". To Abram if water flows, then all elements of sustainability would be in place. Brikke and Davis (1995) also referred to sustainability in rural water supply projects to mean, water projects that are maintained in a condition which ensures an adequate and reliable water supply over a prolonged period of time.

Schouten et al. (2003) on the other hand, defined success of a water project as a system that reliably meets the needs of all the target groups without leaving the poorest un-served.

This study the researcher utilized the more specific, function oriented definition provided by Kimberly (1998), who stated that sustainability in water projects means, ensuring water supply projects continue to operate and they generate expected benefits over time. Kimberly further pointed out that, sustainability is all about ability to maintain initial targeted project service standards. To achieve this, he explained that, sustainability has to be planned from the very conceptualization of the project, in order to come up with strategies that ensure only sustainable projects and interventions are initiated.

\section{Research Methodology}

This study adopted a cross-sectional descriptive survey design. The population of the study comprised of all 73 community water projects and all the beneficiaries of the water projects in Kieni constituency, Kenya. The study used both probabilistic and nonprobabilistic sampling designs. The sample size for the study was 382 community water beneficiaries, 73 community water project chairmen, two district water officers and 9 bank managers. Total sample size was 466 respondents. Data was collected by use of self-administered questionnaires, observation schedule and interview schedules. Data was analyzed by use of inferential statistics mainly Pearson Product Moment Correlation, analysis of variance (ANOVA) and linear regression analysis.

\section{Study Findings}

Table 4.1: Summary of the Results and Hypothesis Testing

\begin{tabular}{|c|c|c|c|c|}
\hline Research Objectives & Hypotheses & Results & Table & Remarks \\
\hline $\begin{array}{l}\text { 1. To establish the extent to } \\
\text { which equity financing } \\
\text { influences sustainability } \\
\text { community of water projects. }\end{array}$ & $\begin{array}{l}\mathrm{H}_{01} \text { There was no significant } \\
\text { relationship between equity } \\
\text { financing and sustainability of } \\
\text { community water projects }\end{array}$ & $\begin{array}{l}\mathrm{r}=0.296^{*} \\
\mathrm{R}^{2}=0.088 \\
\mathrm{~F}=3.662 \\
\mathrm{p}=0.063\end{array}$ & $\begin{array}{l}4.16 \\
4.17 \\
4.18\end{array}$ & $\begin{array}{l}\text { Failure to accept the } \\
\text { null hypothesis, } \\
\text { therefore rejected (at } \\
90 \% \text { ). }\end{array}$ \\
\hline $\begin{array}{l}\text { 2. To assess the extent to } \\
\text { which grant financing } \\
\text { influence sustainability of } \\
\text { community water projects. }\end{array}$ & $\begin{array}{l}\mathrm{H}_{02} \text { There was no significant } \\
\text { relationship between grant } \\
\text { financing and sustainability of } \\
\text { community water project }\end{array}$ & $\begin{array}{l}\mathrm{r}=-0.152 \\
\mathrm{R}^{2}=0.023 \\
\mathrm{~F}=1.303 \\
\mathrm{P}=0.259\end{array}$ & $\begin{array}{l}4.16 \\
4.19 \\
4.20\end{array}$ & $\begin{array}{l}\text { Accept null } \\
\text { hypothesis, }\end{array}$ \\
\hline $\begin{array}{l}\text { 3. To examine the extent to } \\
\text { which debt financing } \\
\text { influences sustainability of } \\
\text { community water projects. }\end{array}$ & $\begin{array}{l}\mathrm{H}_{03} \text { There was no significant } \\
\text { relationship between debt } \\
\text { financing and sustainability of } \\
\text { community water projects }\end{array}$ & \begin{tabular}{|} 
No water project \\
which had \\
acquired debt \\
financing \\
\end{tabular} & & $\begin{array}{l}\text { None of the projects } \\
\text { had debt financing }\end{array}$ \\
\hline $\begin{array}{l}\text { 4. To establish the influence } \\
\text { of the water user fees on } \\
\text { sustainability of community } \\
\text { water projects. }\end{array}$ & $\begin{array}{l}\mathrm{H}_{04} \text { There was no significant } \\
\text { relationship between amount of } \\
\text { water user fees and sustainability } \\
\text { of community water projects. }\end{array}$ & $\begin{array}{l}\mathrm{r}=0.356^{*} \\
\mathrm{R}^{2}=0.312 \\
\mathrm{~F}=16.791 \\
\mathrm{p}=0.00^{\mathrm{b}}\end{array}$ & $\begin{array}{l}4.16 \\
4.21 \\
4.22\end{array}$ & $\begin{array}{l}\text { Reject null } \\
\text { hypothesis, }\end{array}$ \\
\hline $\begin{array}{l}\text { 5. Investigate influence of } \\
\text { capital structure on } \\
\text { sustainability of community } \\
\text { water projects. }\end{array}$ & $\begin{array}{l}\mathrm{H}_{05} \text { There was no significant } \\
\text { relationship between capital } \\
\text { structure and sustainability of the } \\
\text { community water projects. }\end{array}$ & $\begin{array}{l}R^{2}=0.11 \\
F=3.380 \\
p=0.540\end{array}$ & $\begin{array}{l}4.16 \\
4.23 \\
4.24\end{array}$ & $\begin{array}{l}\text { Accept the null } \\
\text { hypothesis, }\end{array}$ \\
\hline
\end{tabular}


The study established that, there exist a moderate positive correlation between equity finance (community contributions) and sustainability of community water projects since the calculated correlation coefficient was $0.296^{*}$. Analysis of Variance (ANOVA) was used to test hypothesis one of the study. The F value was 3.662 which was significant. The null hypothesis one was rejected. Therefore the study concluded that, there was significant relationship between equity financing and sustainability of community water projects. The resultant $\mathrm{R}$ Square was 0.088 which indicated that equity financing accounted for only $8.8 \%$ of the variation in levels of sustainability. Hence, $91.2 \%$ of the variation in levels of sustainability could not be explained by equity financing.

On objective two, the calculated Pearson Product Moment correlation coefficient ( $\mathrm{r}$ ) was negative 0.152 , depicted a weak negative correlation between grant financing and sustainability of community water projects that was not significant. Therefore, there was a weak inverse relationship between grant financing and level of sustainability of community water projects. The calculated F statistic was 1.303 , which was also not significant at $\mathrm{p}=0.259$. The null hypothesis two was accepted, hence it was concluded that, there was no significant relationship between grant financing and sustainability of community water projects. The resultant $\mathrm{R}$ Square $=0.023$ in the regression model summary indicated that grant financing accounted for only $2.3 \%$ of the variation in levels of sustainability. Grant financing therefore was not a major factor that influence sustainability of community water projects.

On debt financing, it was established that, none of the project had obtained a form of debt finance. The reasons was that, they were afraid they may not be able to repay the loans, their collection as water user fees may not be able to service the loan or income inconsistency, loans are expensive, lack of knowledge as to how to obtain the loans.

Objective four of the study sought to establish the influence of the water user fees on sustainability of community water projects. The calculated Pearson Product Moment Correlation coefficient $r$ was $0.356^{*}$, which depicted a moderate but positive correlation between water user fee and sustainability of community water projects. The correlation was also significant. It was therefore concluded that there was a significant moderate positive relationship between water user fee and level of sustainability of community water projects. The same conclusion was made, that is, rejecting hypothesis four since the calculated F statistics was 16.791, which was significant at $\mathrm{p}=0.00$. Hence, there was significant relationship between water user fee and sustainability of community water projects. The R Square $=0.312$ in the regression model summary indicated that water user fee accounted for $31.2 \%$ of the variation in levels of sustainability.

Hypothesis five was stated as; there was no significant relationship between capital structure and sustainability of community water projects. Capital structure was represented by combination of equity financing, grant financing and water user fee. Sustainability was assessed based on level of functionality over time, functionality of water systems and adequacy of water provision by community water projects. The calculated F statistic was 0.380 , which was not significant at $\mathrm{p}=0.540$. Therefore, the null hypothesis five was accepted; hence, there is no significant relationship between capital structure and levels of sustainability of community water projects. 


\section{Conclusions and Recommendations}

The study concluded that, there was a moderate relationship between equity financing and level of sustainability of community water projects and equity financing had significant relationship with sustainability of community water projects. Therefore, the study recommends that, the water policy makers should device ways of increasing community contribution to water projects to boost sustainability. There should be a better way of community mobilization and involvement in community water projects especially regarding equity contribution.

The study established that none of the water projects had obtained any form of debt finance. Therefore, this study recommends that financial institutions do a sensitization program with key water stakeholders with a view of giving community water stakeholder mechanisms of taking advantage of debt financing in water projects as an instrument of boosting financing of community water projects.

The study also found out there exist a negative correlation between grants or free funds from donors and sustainability of community water projects. This study recommends that donors create a mechanism for repayment of the donated funds. By ensuring the grant become debt, improvement in utilization of the funds and management community water projects will be realized.

\section{References}

Abrams, L. (1998). Understanding sustainability of local water services. Retrieved from http://www.africanwater.org/sustainability.htm

Adam, C.S. \& Bevan, D.L. (2006). Aid and the Supply Side: Public Investment, Export Performance, and Dutch Disease in Low-Income Countries. World Bank Economic Review.20, 261-90.

African Development Fund (ADF) (2005). Ethiopia;Rural Water Supply and Sanitation Program Appraisal Report.African Development Fund, infrastructure department; north, east and south, ONIN June 2005.

Adida, A. (2012). Financial Sustainability of Rural Water Supplies in Western Kenya.Faculty of Civil Engineering Department of Water Management and Sanitary Engineering Section: Delft University of Technology.

Baumann, E. (2006). Do Operation and Maintenance Pay? Waterlines, 25.

Beyene, H. (2012). Factors affecting the Sustainability of Rural Water Supply Systems: The Case of MechaWoreda, Ambara Region, Ethiopia: A Project Paper Presented to the Faculty of the Elshorst Graduate School of Cornell University in Partial Fulfillment of the Requirements for the Degree of Master of Professional Studies.

Binder D. (2008). Sustainability of Water Service Delivery in Rural Environment: PastApproaches and the Way Forward February 2008: A Project Paper Presented to the Faculty of the Graduate School of Cornell University

Boland, J. \& Whittington, D.(2000). The political Economy of Increasing Block Water Tariffs in Developing Countries. InThe Political Economy of Water Pricing Reforms. Oxford: Oxford University Press.

Brikke, F. (2000).Operation and Maintenance of Rural Water Supply and Sanitation Systems, A training Package for Managers and Planners, Geneva: IRC International Water and Sanitation Center, WHO,.

Brikke, F. (1994).Operation and Maintenance of Rural and Urban Water Supply and Sanitation Systems: a workshop Report in Support of the Africa 2000 Initiative, 8-12 November 1993, Harare, Zimbabwe.

Brikke, F. \& Davis, J. (1995).Making your Water Supply Work: operation and Maintenance of Small water Supplies.IRC Occasional paper Series 29, IRC International Water and Sanitation Center. 
Brikke, F. \& Rojas J. (2001).Key factors for sustainable cost recovery in the context of community managed water supply. Occasional paper series 32-E. Delft, The Netherlands, IRC International Water and Sanitation Centre. Retrieved from www irc.nl/content//download/2568/26552/file/op32e.pdf.

Briscoe, J. \& de Ferranti, D. (1998). Water for rural communities: helping people help themselves. Washington DC: The World Bank

Cheong, F. (2016). Equity Financing and Debt Financing. PBE Paper-Management Accounting and Finance: Macao Polytechnic

Gine, A. \& Perez-Foguet, (2008). Sustainablity assessment of National Rural Water supply Program in Tanzania. Natural resources Forum Volume 32 pages 327-342.

Gow, D. \& J. Franken H. (1994). (Local Governments and participation" paper presented at workshop on participatory development, 17-20 may 1994. the World Bank.

Harvey, P. \& Reed, R. (2007). Community-Managed Water Supplies in Africa: Sustainable or Dispensable? Community Development Journal 42(3), 365.

Harvey, P.A. \& Reed, R.A. (2004). Rural Water Supply in Africa: Building Blocks for Handpump Sustainability. Water, Engineering and Development Centre (WEDC).Loughborough University, UK

Haysom, A. (2006). A study of the factors affecting sustainability of rural water supplies in Tanzania,Msc Thesis, Silsoe: cranfield university. Retrieved from www.wateraid.Org/other/startdownload.asp.

International Fund for Africa Development (IFAD) (2007).IFAD Strategic Framework 2007-2010.Rome.

Kenya Food Security Steering Group (2012).Nyeri District Short Rains 2011/2012 Assessment Report - 25th February, 2012 (Unpublished)

Kikula, I.S. (1999). Lessons from Twenty-Five Years of Conservation and Seven Years of Research Initiatives in the Kondoa Higblands of Central Tanzania.Ambio 28(5), 444-49.

Kimberley, C. (1998). Guidance Manual on Water Supply and Sanitation Programs, WEDC, London, UK.

Kleeimer, E. (2002). The Impact of Sustainability: An Analysis of the Malawi Rural Piped Scheme Program', World Development Volume 28, 929-944.

Kleemeier, E. (2000). The Impact of Participation on Sustainability: An Analysis of the Malawi Rural Piped Scheme Programme. World Development Volume 28, No. 5 pages 929-944.

McLaughlin, T. (2000).In Cash There is Opportunity. (The Nonprofit Quarterly, Winter 2000).

McLaughlin, T.(2008). More from Nonprofits Now Means Less in the Future. The Financial Times, December 9, 2008).

Miller, C. (2003). Hidden in Plain Sight: Understanding Nonprofit Capital Structure. (The Nonprofit Quarterly, Spring 2003).

Miller, C. (2002). The Business Roots of Capacity and Mission at Nonprofits, (Nonprofit Finance Fund, 2002).

Ministry of Water and Irrigation, (2010). Annual Water Sector Review 2009, 48-49 "WSS Tariffs" Retrieved 1 March 2018.

Ministry of Water and Irrigation, (2007).Annual Water Sector Review 2007, 11-16 "Water sector financial turnout". Retrieved 1 March 2018.

Ministry of Water and Irrigation, (2007).Value For Money Study - Draft Report, Ministry Of Water And Irrigation: Nairobi

Mukherjee, N. \& Van Wijk C. (2003)."Sustainability Planning and Monitoring in Community Water Supply and Sanitation”.Water and Sanitation program/IRC2003.

Musonda, K. (2004). Issues Regarding Sustainability of Rural Water Supply in Zambia.The University of South Africa, M.A in Social Science Dissertation.

MWI, (2005).Assessing Unit Costs for W ater Supply And Sanitation Services In Kenya. Government Printer: Nairobi.

Nkusu, M. (2004), Aid and the Dutch Disease in Low-Income Countries: Informed Diagnosis for Prudent Prognoses. IMF working paper No. 04/49.

Nonprofit Finance Fund (2009). Linking Mission and Money: An Introduction to Nonprofit Capitalization, (Nonprofit Finance Fund, 2009).

Nyoni, J. M. (1999). Water Pricing Issues In Developing Country: Case of Zimbabwe IInternational Journal of Social Economicshttp://elibrary.ru/contents.asp?issueid=247136.

Nyong, A.O. \&Kanaroglou, P.S. (1999). Domestic Water Demand in Rural Semi-Arid Northeastern Nigeria: Identification of Determinants and Implications For Policy. Environment And Planning. A 31, 2127-44.

OECD (2008). Donor Profile on Aid to Water Supply and Sanitation. OECD.DAC Secretariat and World Water Council. www.OECD.org/dac/stats/crs/water 
Republic of Kenya, (2014).Economic Survey 2013 Highlights. Nairobi: Government Printer

Republic of Kenya, (2007).National Water Services Strategy: 2007-2015. Ministry of Water and Irrigation: Nairobi.

Rural Water Supply Networks (RWSN) (2009). Myth of Rural Water Supply Sector. RWSN Perspective paper No. 4 July 2009.www.rwsn.ch/documentation/skatdocumentation2009-07-27.8158674790/file. Accessed 2012.

Scanlon, J., Cassar, A. \&Nemes, N. (2004).Water as a Human Right?IUCN, Gland, Switzerland and Cambridge, UK.Retrieved from http:www.data.iucn.org/dbtw-wpd-edocs/EPLP-051.pdf.

Schouten, T \& Moriarty, P. (2004).Scaling up the community management of rural water supply.Water lines Volume 23 No. 2 October 2004.

Schouten, T. \& Moriarty, P. (2003).From System to Service - draft The Hague, The Netherlands, IRC International Water and Sanitation centre and ITDG, August 2003.

Shaw, D. (2012). An Assessment of Rural Water Supply Sustainability in Monæe District, Zambia. A dissertation submitted to the University of Bristol in accordance with the requirements of the degree, Master of Science by advanced study in Water \& Environmental management, in the Faculty of Engineering.

Sutton, S. (2004). Preliminary Desk Study of Potential for Self Supply in Sub-Sabaran Africa, UK SC: Water Aid and the Rural Water Supply Network.

Swaroop, V. \& S. Devarajan (1998): The Implications of foreign aid fungibility for development assistance. World Bank Policy Research Working Paper No. 2022.

UNHCR, (1997).Partnership in Water Sector for Cities in Africa. Report of Cape Town Consultants, Cape Town: UNHS/DWSF/UNDP

United Nations, (1992).Rio Declaration on Environment and Development, report of the United Nations Conference on Environment and Development, Rio de Janeiro (3-14 June).

UNICEF \& WHO, (2012).Progress on Drinking Water and Sanitation: 2012 update, WHO/UNICEF Joint Monitoring Programme for Water Supply and Sanitation, United States of America.

United State Environmental Protection Agency, (2014). Water Facts: Making A Difference in Water. XPV Capital Corporation. www.xpvcapital.com/globalwater-infrasteructurespending. (accessed on 10/11/2014).

WHO,\& UNICEF (2010). Joint Monitoring Programme. Water Supply and Sanitation in Kenya, Accessed on August 22,2012.

WHO \& UNICEF, (2000).Joint Monitoring Programme for Water Supply and Sanitation.. -Global Water Supply and Sanitation Assessment 2000 Reportll

WHO, (2000), Global Water Supply and Sanitation Assessment 2000 report.New York: WHO/UNICEF

WHO, (1993).Guidelines for Drinking Water Quality Volume 1 Recommendations $2^{\text {nd }}$ edition World Health Organisation, Geneva.

WHO (1996).Water supply and sanitation sector monitoring report 1996: sector status as of 31 December 1994. WHO/EQS/96.15. World Health Organisation, Geneva, 1996.

Whittington, D. (2003). Municipal water pricing and tariff design: a reform agenda for South Asia, Water Policy, 5, 61-76.

Whttington, D., Davis, J., Prokopy L., Komives, K., Thorsten, R., Lukacs, H,Bakalian, A., \&Wakeman, W., (2008). How well is the demand-driven, community management model for rural water supply systems doing? Evidence from Boliva, Peru, and Ghana.The University of Manchester Brooks World Poverty Institute, BWPI Working Paper 22.

World Bank (2011).Financing Small Piped W ater Systems in Rural and Peri-urban Kenya.World Bank ": New York.

World Bank (1992) "Village Infrastructure Project for Java”. Staff Appraisal Report, Country Department II.East Asia and Pacific Region.The World Bank Washington, D.C.

World Bank (1993). "Village Infrastructure Project for Java”.Staff Appraisal Report.Country Department III.East Asia and Pacific Region. The World Bank. Washington, D.C. April 26.

World Bank, (1996).The World Bank Participation Sourcebook. World Bank, Washington DC, http://www.worldbank.org/wbi/sourcebook/sbpdf.htm (Accessed: June 05 2013).

Yahaya, S. (2004).Meeting targets for Water Supply and Sanitation: the African Challenge. Operation Policy and Review department, ADB pp. 323, Tunis.

Young, D. (2002). The Perils of Accepting Large (Multi-Million Dollar) 'Named' Gifts From Major Donors. (NCNE Website, 2002). 